\title{
Management practices and contribution of village chickens to livelihoods of communal farmers: The case of Centane and Mount Frere in Eastern Cape, South Africa
}

\author{
BUSISIWE GUNYA ${ }^{1,3, \bullet}$, VOSTER MUCHENJE ${ }^{2}$, MASIBONGE GXASHEKA ${ }^{3}$, LOUIS THOBELA TYASI ${ }^{3}$, \\ PATRICK JULIUS MASIKA ${ }^{1,2}$ \\ ${ }^{1}$ Department of Livestock and Pasture Science University of Fort Her. Private Bag X1314, Alice, 5700, South Africa \\ Tel./fax.: +27-15-2684618, ^email: Busisiwe.Gunya@ul.ac.za \\ ${ }^{2}$ Fort Cox College of Agriculture and Forestry. Private Bag X2187, King William's Town, 5600, South Africa \\ ${ }^{3}$ Department of Agricultural Economics and Animal Production, University of Limpopo. Private X1106, Sovenga, 0727, South Africa
}

Manuscript received: 6 January 2019. Revision accepted: 7 March 2020.

\begin{abstract}
Gunya B, Muchenje V, Gxasheka M, Tyasi LT, Masika PJ. 2020. Management practices and contribution of village chickens to livelihoods of communal farmers: The case of Centane and Mount Frere in Eastern Cape, South Africa. Biodiversitas 21: 1345-1351. This study was conducted to determine village chickens production practices and their contribution to the livelihoods of farmers in rural households of the Eastern Cape Province, South Africa. Data were gathered using a questionnaire survey of 150 households, which were identified by the use of snowball sampling. Village chickens were the most livestock species kept by farmers, mostly owned by women (79.61\% in Centane and $81.06 \%$ in Mount Frere) and were kept for household food needs. Some farmers (21.92\% and 25.31\%) also occasionally sold their chickens at an average of R80 (\$7.22) per bird. Most (93.13\% and 76.44\%) chickens flocks were provided with supplementary feed. The majority of farmers $(80.31 \%$ and $88.33 \%)$ provided shelter for their chickens. The causes of chicken losses were reported to be diseases, predators, parasites and theft. The most cited disease problem was Newcastle $(50.32 \%$ and $66.02 \%)$ while major predators were eagles $(84.91 \%$ and $81.82 \%)$. The most common internal parasites were roundworms and tapeworm whilst the most reported external parasites were poultry lice and mites. The majority of farmers $(94.51 \%$ and $92.21 \%)$ reported using chicken manure to improve the fertility of soils in their gardens. Chickens had a varied social role in the two areas, i.e., donation (61.63\% and $68.82 \%)$ to neighbors and relatives. The majority of farmers (84.90\%) in Centane didn't use chickens for cultural purposes whilst the majority (55.85\%) in Mount Frere used chickens for cultural purposes. The present study showed that village chickens have a contribution to the livelihoods of rural households.
\end{abstract}

Keywords: Communal farmers, livelihoods, management, practices, village chickens

\section{INTRODUCTION}

Village chickens are the most common type of livestock in many rural areas in South Africa. They are reared under the extensive system. They are among the most adaptable domestic animals that can survive in harsh environments. Nevertheless, village chicken production is based on extensive farming which is characterized by low productivity and poor management. They are maintained with few or no inputs for housing, feeding and health care (Muchadeyi et al. 2004). Furthermore, they obtain most of their diet by scavenging for food and water around the home and village. They are prolific, easily reared and their output can be generally expanded more rapidly and easily than other livestock (Reta 2009).

Village chickens play an important role in poverty alleviation of rural farmers (Fattah 1999; Aklilu et al. 2008) by providing a cheap source of protein, in the form of meat and eggs (Adongo 2004; Copland and Alders 2005; Mack et al. 2005). Rural poultry has also been reported to play a significant role in income generation. They also contribute to socio-cultural functions such as traditional ceremonies, hospitality and exchange gifts to strengthen relationships
(Aklilu et al. 2008). Hence, they contribute significantly to the livelihoods of people who keep them.

Village chickens are important, despite their poor production, in providing valuable high-quality protein, poverty alleviation and income and food security. Despite their importance, village chickens are sometimes ignored. Therefore, there is lack of information on the status of chicken production and contribution of village chickens to the livelihoods of most communal households of South Africa. This study will facilitate the understanding of the significance of village chickens and also outline the challenges that farmers face. Therefore the objective of this study was to evaluate the village chicken production system and to estimate their role to rural households.

\section{MATERIALS AND METHODS}

\section{Study area}

The study was conducted in two Municipalities: Amathole District Municipality and Alfred Nzo District Municipality in Eastern Cape Province of South Africa (Figure 1). In Amathole District Municipality, the study 
was conducted in the villages of Centane which is in Umnquma local municipality. It lies along longitude $28^{\circ}$ $316^{\prime} \mathrm{E}$ and latitude $32^{\circ} 5167^{\prime} \mathrm{S}$ at an altitude of $456 \mathrm{~m}$ above sea level. This area forms part of the coastal Eastern Cape which is characterized by high regular rainfall throughout the year (700-1000 mm/ annum) with most rains occurring in spring and summer months (October to March) particularly in the lowland coastal belt, extending 30 to 60 $\mathrm{km}$ inland (Mwale and Masika 2009). In winter, the average minimum temperature is $7^{\circ} \mathrm{C}$ while the maximum temperature is $21^{\circ} \mathrm{C}$. In Alfred Nzo District Municipality, the study was conducted in villages of Mount Frere which is in Umzimvubu local municipality which lies along longitude $28^{\circ} 9833^{\prime} \mathrm{E}$ and latitude $30^{\circ} 9167^{\prime} \mathrm{S}$ at an altitude of $1321 \mathrm{~m}$. This area is situated far from the coast which is characterized by low rainfall throughout the year mean annual rainfall of $671 \mathrm{~mm}$, with most rainfall occurring mainly during midsummer. It receives the lowest rainfall (7 $\mathrm{mm})$ in June and the highest $(110 \mathrm{~mm})$ in January. The annual temperature ranges from $18.3^{\circ} \mathrm{C}$ in June to $25.9^{\circ} \mathrm{C}$ in January. The region is coldest during July when the temperature drops to $3.7^{\circ} \mathrm{C}$ (Phininzi and Ngetar 2017).

\section{Sampling procedure}

Snowball sampling technique was used to select 150 households that were interviewed in two villages of Centane and three villages of Mount Frere, the respondents were asked to give referrals to other persons believed to fit the study requirements. Only those farmers who owned chickens and willing to participate in this study were considered. The studied villages were chosen by the researchers with the help of extension officers. The chosen five villages had significant number of households farming with chickens.

\section{Data collection}

The questionnaire was pre-tested before use in the survey. A total of 150 structured questionnaires were administered by a personal interview with households that owned village chickens in selected villages. Information on management practice and contribution of chickens to the livelihoods of farmers was collected under the following categories: demography information, livestock inventory, chicken nutrition, diseases and parasites, housing and roles of chickens.

The majority $(49.31 \%)$ of households were maleheaded in Centane whereas in Mount Frere were femaleheaded $(58.42 \%)$ as shown in Table 1 . The majority of chicken farmers were female farmers, $54.42 \%$ and $64.94 \%$, at Centane and Mount Frere, respectively. About 69.86\% and $57.14 \%$ of farmers at Centane and Mount Frere respectively, were married. The educational background of the majority farmers $(41.09 \%)$ at Centane was secondary level followed by tertiary level $(36.98 \%)$ while at Mount Frere was primary level $(45.45 \%)$ followed by secondary level (32.48). The highest $(64.44 \%$ and 67.54$)$ household size was less than five. Table 1 shows that $86.29 \%$ of participants at Centane and $51.95 \%$ at Mount Frere were not employed followed by pensioners.

\section{Data analysis}

The frequencies of demographic characteristics (age, gender, education, marital status, employment status, household size) of selected farmers were determined using Proc Freq of SAS (version 9.1.3). Chi-square test was used to determine degree of association between categorical variables: demographic, management practices and roles of village chickens.
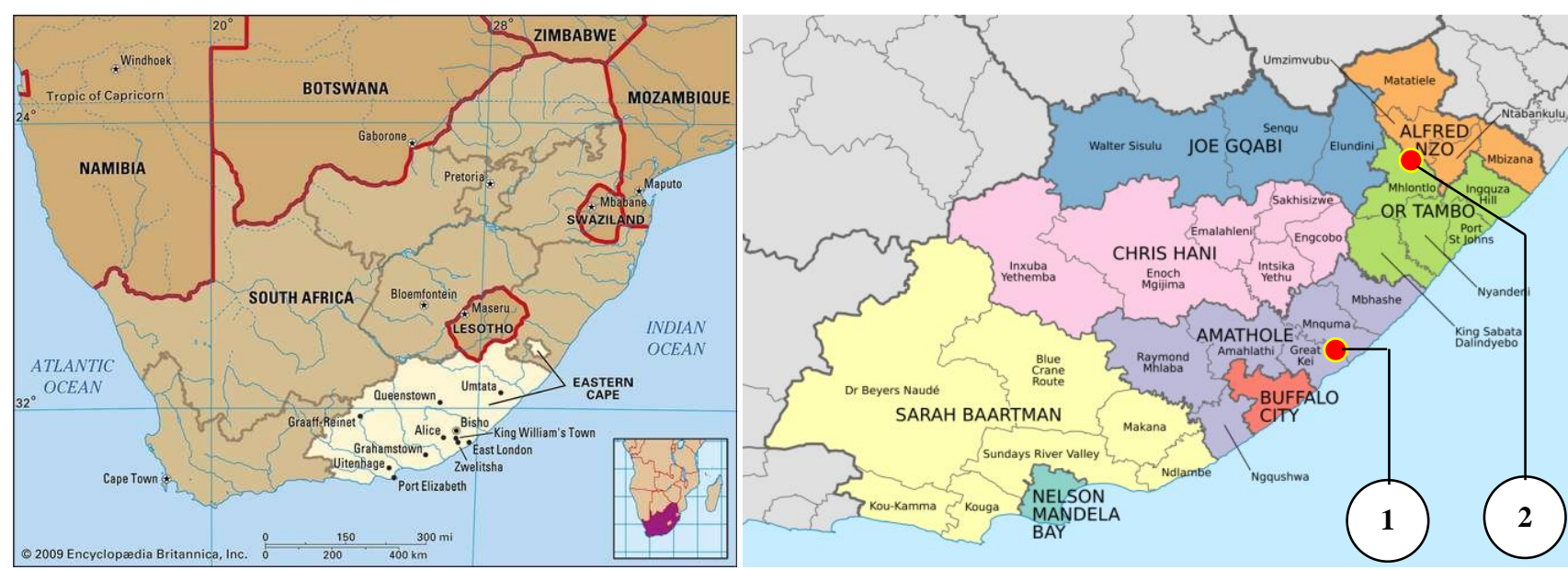

Figure 1. Locational map of Centane (1) and Mount Frere (2), Eastern Cape Province, South Africa 
Table 1. Demographic characteristics of household head chicken farmers in Centane and Mount Frere

\begin{tabular}{|c|c|c|c|c|c|}
\hline \multirow{2}{*}{ Characteristics } & \multirow{2}{*}{ Class } & \multicolumn{2}{|c|}{ Centane } & \multicolumn{2}{|c|}{ Mount Frere } \\
\hline & & $\%$ & Freq & $\%$ & Freq \\
\hline \multirow[t]{3}{*}{ Head of the family } & Father & 49.32 & 36 & 36.38 & 28 \\
\hline & Mother & 38.36 & 28 & 58.42 & 45 \\
\hline & Children & 12.32 & 9 & 5.20 & 4 \\
\hline \multirow[t]{2}{*}{ Gender } & Male & 46.58 & 34 & 35.06 & 27 \\
\hline & Female & 54.42 & 39 & 64.94 & 50 \\
\hline \multirow[t]{4}{*}{ Age } & $<20 \mathrm{yrs}$ & 5.34 & 4 & 0.00 & 0 \\
\hline & $21-40 \mathrm{yrs}$ & 16.43 & 12 & 12.99 & 10 \\
\hline & $41-60 \mathrm{yrs}$ & 41.09 & 30 & 45.45 & 35 \\
\hline & $>60 \mathrm{yrs}$ & 36.99 & 27 & 41.55 & 32 \\
\hline \multirow[t]{4}{*}{ Education } & No formal & 28.76 & 21 & 18.18 & 14 \\
\hline & Primary & 32.87 & 24 & 45.45 & 35 \\
\hline & Secondary & 41.09 & 26 & 32.48 & 25 \\
\hline & Tertiary & 36.98 & 2 & 3.89 & 3 \\
\hline \multirow[t]{3}{*}{ Marital status } & Single & 42.20 & 15 & 35.42 & 4 \\
\hline & Married & 69.86 & 51 & 57.14 & 44 \\
\hline & Widow & 9.59 & 7 & 24.68 & 19 \\
\hline \multirow[t]{3}{*}{ Household size } & $<5$ & 64.44 & 47 & 67.54 & 52 \\
\hline & $6-10$ & 32.87 & 24 & 57.15 & 23 \\
\hline & $11-15$ & 2.73 & 2 & 2.59 & 2 \\
\hline \multirow[t]{4}{*}{ Employment } & $\begin{array}{l}\text { Not } \\
\text { employed }\end{array}$ & 57.53 & 42 & 53.34 & 40 \\
\hline & Informal & 2.74 & 2 & 5.33 & 4 \\
\hline & Employed & 6.85 & 5 & 5.33 & 4 \\
\hline & Pensioner & 32.88 & 24 & 35.00 & 27 \\
\hline
\end{tabular}

\section{RESULTS AND DISCUSSION}

\section{Livestock inventory}

Village chickens were the most livestock species kept by farmers in Centane and Mount Frere, followed by cattle, sheep, goats, pigs, geese, and ducks (Figure 1). Furthermore, chickens were ranked as the most important livestock by most farmers in both study sites. Chickens were mainly kept for consumption of $68.95 \%$ and $74.54 \%$ at Centane and Mount Frere, respectively, however, few farmers $(1.38 \%$ and $2.61 \%)$ used their chickens for sales. On the other hand, cattle were mainly kept for sales or as a bank $(19.31 \%)$ in Centane whereas in Mount Frere were for draft power (16.99\%). Sheep were mainly kept for sales $(23.44 \%)$ in Centane whereas were kept for wool production $(9.81 \%)$ in Mount Frere. Moreover, goats were mainly kept for cultural rituals (22.68\% and $39.23 \%$ ) in both communities.

\section{Ownership}

Although chickens belong to the family at large, specific patterns of ownership were observed as shown in Figure2. Women-owned the majority of chickens $(78.61 \%$ and $81.06 \%$ ) in Centane and Mount Frere, respectively. Most of farmers $(53.829 \%$ and $45.76 \%)$ in Centane and
Mount Frere sourced their chickens through buying, whereas few obtained them as a gift. In Mount Frere a very proportion $(1.31 \%)$ obtained their chickens through exchanging.

\section{Diseases and parasites}

Diseases were reported to be the major causes of chicken losses, in both study sites. Newcastle disease was perceived to be the most common followed by Marek's disease and diarrhea (Table 2). Most of the respondents $(99.31 \%$ and $85.01 \%)$ used ethnoveterinary medicines specifically Aloe to control diseases.

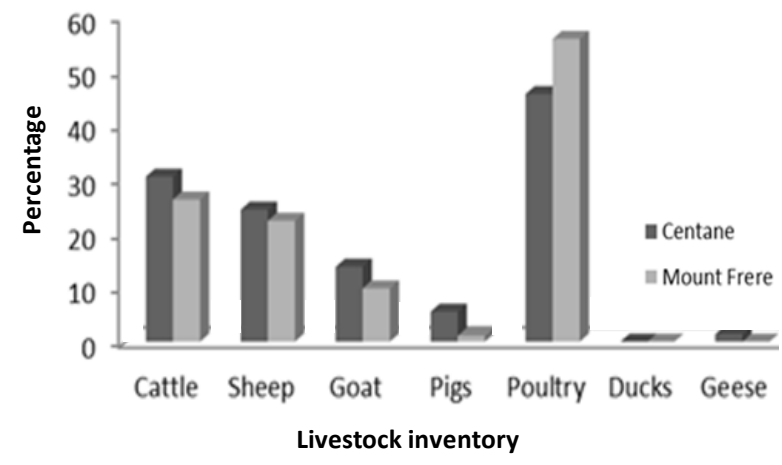

Figure 1. Average livestock ownership in Centane and Mount Frere, South Africa

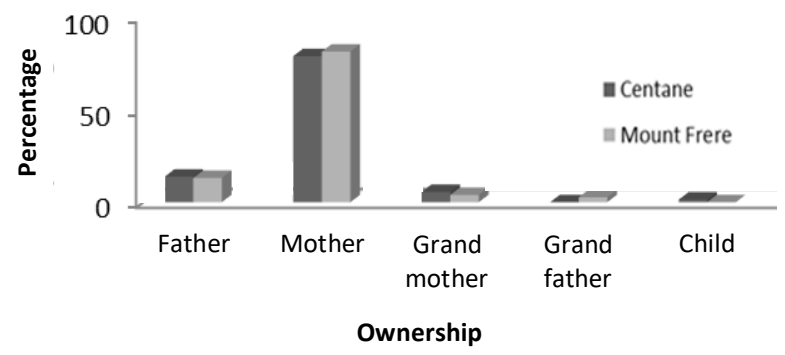

Figure 2. Ownership of chickens in Centane and Mount Frere, South Africa

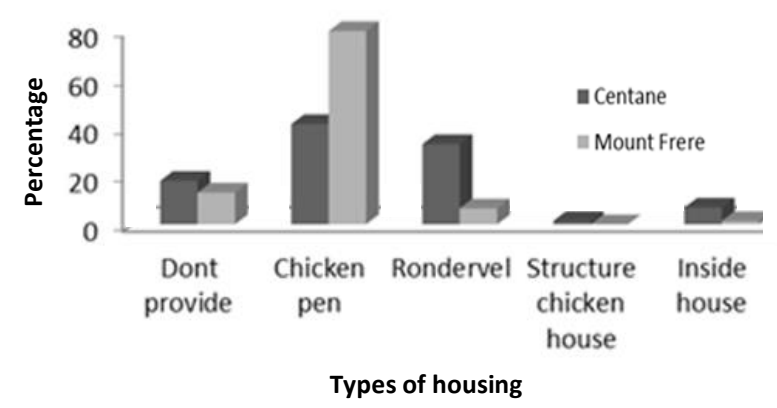

Figure 4. Kind of housing provided for chickens in Centane and Mount Frere, South Africa 
Table 2. Disease, predation and theft in Centane and Mount Frere, South Africa

\begin{tabular}{lcc}
\hline Attributes & Centane (\%) & Mount Frere (\%) \\
\hline Diseases & 50.31 & 66.02 \\
New Castle & 12.53 & 19.62 \\
Marek's & 11.03 & 13.07 \\
Diarrhea & 26.13 & 1.29 \\
Other diseases & & \\
Predation & 84.91 & 81.83 \\
Eagles & 8 & 8 \\
Cats and dogs & 7.09 & 10.18 \\
Wild animals & & \\
Theft & 57,53 & 28.56 \\
Yes & 42.47 & 71.44 \\
No & & \\
\hline
\end{tabular}

In Centane, chicken tapeworms were the main internal parasites whilst in Mount Frere, it was roundworms. Internal parasites were prevalent during the summer season, although some farmers were not aware of the existence of internal parasites in chickens. Farmers who controlled internal parasites used mainly Aloe (53.77\% and $18.27 \%$ ) whereas the rest did not use any control.

The majority of farmers reported experiencing problems with external parasites in their chickens. In both communities, mites were the most common external parasites followed by lice. External parasites occurred mostly during the summer season. Farmers reported that they use wood ash, blue death, and chicken spray dip to eliminate external parasites from chickens.

\section{Predation}

Most of the respondents reported chicken predation to be a concern. Eagles were the most common predators (Table 2) that were found at Centane and Mount Frere, respectively. Cats and $\operatorname{dogs}$ were also a problem as recorded by $8 \%$ of the respondent of both the study sites. To control chicken predation farmers enclosed their chickens in chick net $(46.66 \%$ and $64.00 \%)$. Farmers control predation by eagles by shouting at them $(26.03 \%$ and $36.37 \%$ ).

\section{Theft}

The theft was reported to be a problem by $57.53 \%$ of chicken farmers in Centane, whereas some farmers (71.44\%) from Mount Frere did not (Table 2). In Centane some of the farmers $(24.65 \%)$ minimize theft of chickens by sleeping with them inside their houses, while farmers $(12.99 \%)$ in Mount Frere reported that they used dogs.

\section{Housing}

The majority of chicken farmers $(80.81 \%$ and $88.33 \%)$ provided shelter for their chickens whilst the rest $(19.17 \%$ and $11.69 \%$ ) did not, at Centane and Mount Frere, respectively. The chicken pen was the most $(40.09 \%$ and $9.09 \%$ ) type of housing provided by farmers for their chickens while structured chicken houses were the least. Few farmers (30\%) did not provide houses for their chickens. Their chickens $(12.33 \%$ and $7.79 \%)$ roosted inside the houses at night to prevent theft and others in kraal $(4.11 \%$ and $1.31 \%)$, open space $(1.38 \%$ and $2.59 \%)$ and trees $(1.38 \%$ and 0$)$ at Centane and Mount Frere, respectively.

The major challenge $(41.09 \%$ at Centane and $45.39 \%$ at Mount Frere) faced by chicken farmers to house their chickens was cleaning the chicken houses followed by no proper housing $(12.32 \%$ and $10.38 \%)$ theft $(10.95 \%$ and $0 \%)$, external parasites $(5.48 \%$ and $6.47 \%)$, predators $(0.0 \%$ and $5.34 \%)$ and brooding place $(1.38 \%$ and $1.31 \%)$. Some farmers $(60.00 \%)$ reported not having challenges concerning housing chickens.

\section{Contribution of chicken to nutrition}

All the respondents $(100 \%)$ in both sites kept village chickens to address the food needs of their households. Farmers in Centane normally consumed chickens monthly, whilst in Mount Frere consumption of chickens was rarely done. In both Centane and Mount Frere, most farmers $(60.26 \%$ and $57.14 \%)$ reported that they consume one chicken at a time. Consumption of eggs varied, the majority of respondents $(86.38 \%$ and $80.52 \%)$ ate eggs from village chickens, though few (26.03\% and19.48\%) did not. The major factor influencing egg consumption was that it would reduce the number of eggs for incubation. Although some farmers consume eggs from the village chickens, most cease from doing so to provide as many eggs as possible for incubation. Other reasons farmers reported for not consuming eggs were yellowness of egg yolk, number of chickens and age of chickens.

\section{Contribution of chickens to economics}

The majority of chicken farmers $(78.07 \%$ and $87.03 \%)$ did not sell chickens at Centane and Mount Frere. The reasons for not selling chickens were having few chickens, keeping them for consumption only, and not having a market. However, there were few farmers $(21.92 \%$ and $12.99 \%$ ) who occasionally sold some of their chickens within the community. The major reason for selling chickens was the need for cash. The prices of the chicken were at an average of R80 (\$7.22). Most of the farmers (97.24\% and $97.41 \%$ ) did not sell eggs, manure and feathers because there were no markets.

\section{Contribution of chickens to socio-cultural}

The majority of farmers $(94.51 \%$ and $92.21 \%)$ applied chicken manure to improve the fertility of their vegetable gardens, instead of using organic fertilizers. Some farmers did not use chicken manure because: they did not collect manure, did not have a garden, used kraal manure instead, and lacked the necessary knowledge. Most of farmers (61.63\% and 68.82) in Centane and Mount Frere donated their chickens to their neighbors and relatives. Some farmers $(38.36 \%$ and $31.17 \%)$ did not donate chickens because their chickens were few. The majority of farmers $(84.90 \%)$ in Centane didn't use chickens for cultural purposes. Farmers in Centane reported that they use goats and cattle to perform their rituals not chickens. However, the majority $(55.85 \%)$ in Mount Frere used chickens for cultural purposes. 


\section{Discussion}

Village chickens were the most livestock species kept by farmers, finding in line with the results by Mwale and Masika (2009) and Mutibvu (2012). This shows that every household owned a chicken (Mwale and Masika 2009). Furthermore, chickens were ranked as the most important livestock by most farmers in both study sites. Similar results have been reported by Mutibvu (2012) and Nyoni and Masika (2012). This happened because some farmers might not own other livestock or the number of other livestock (cattle, sheep, goats, pigs, geese, and ducks) was fewer as compared to chickens, hence village chickens were regarded as very important livestock.

Ownership of chickens was predominantly by women. This may be attributed to the role played by women on poultry management activities such as cleaning, feeding, and watering. In addition, men own and control large animals (cattle, goat, and sheep) and chickens are directly accessible to women. However, men tend to be involved in chicken production when the enterprise becomes large while women tend to be largely confined to production at a subsistence level (Mtileni et al. 2009). This finding is in agreement with reports of Muchadeyi (2004), Halima (2007), Abubakar et al. (2007), Moges et al. (2010) and Mtileni et al. (2009), who observed that women were more responsible for the chicken management.

Supplementary feed was provided in the form of maize grain to improve the nutrition of their birds absolutely to enhance the rapid growth rate and weight gain. The use of maize grain as a supplement may be attributed to easily availability of maize to farmers since maize is the most common available crop in the Eastern Cape Province. The provision of feed supplementation for village chickens specifically maize was also reported by Muchadeyi et al. (2004), Mwale and Masika (2009), and Nyoni and Masika (2012). Chickens were fed separately based on their different stages of growth to prevent competition between old birds and chicks. This finding contradicts the results found by Muchadeyi et al. (2004) and Nyoni and Masika (2012), who reported that chickens at different stages of growth were left to compete for the same feed. Most farmers did not provide protein feed for their chickens presumably because the communal farmers cannot afford to purchase them due to their expenses. Chickens scavenged for their protein source on grass, worms, and insect. Protein-rich materials such as earthworms, insects, and grass can help to meet the need for protein of birds.

Diseases were the major causes of chicken losses. This may be due to poor housing, poor hygiene and inadequate feeding which predispose chickens to diseases (Selam and Kelay 2013). Diseases become a problem when drugs and vaccines are not easily accessible to farmers. Similar findings have been reported by Mtilene et al. (2009) and Dinka et al. (2010), that Newcastle was the most problematic disease. Chicken death rates were highest during summer season. This finding is similar to the work done by Dinka et al. (2010), who reported that Newcastle was mostly prevalent during rainy season (June to August). Internal parasites were also a problem for chickens. Major factors associated with the high prevalence of internal parasite infestation are the type of production system which is basically a free-ranging, low-input low-output that allows the chickens to easily pick up infections (Mwale and Masika 2009). This was also substantiated by Muchadeyi et al. (2007), who specified that in extensive management systems where chickens have access to outdoor areas, and not confined, chickens have a greater diversity of parasite infestations. Most of farmers used Ethno-Veterinary medicine specifically aloe to control diseases and internal parasite.

In both communities, mites were the most common external parasites followed by lice. This result is in agreement with the finding of Nnadi and George (2010). Lice and mites can cause chick mortality attributed to starvation and immune depression infestation (Nnadi and George 2010). External parasites result in slow growth rates and reduced egg production of chickens (Gabanakgosi et al. 2012). Furthermore, predation was anxiety for farmers. Eagles were the most common predators, finding contradicts the results by Dinka et al. (2010), who found snakes, rats, dogs and foxes were the main predators. This challenge of predation can be resolved through monitoring chickens during scavenging period (Mapiye et al., 2008), and constructing proper housing for chickens (Kusina et al. 2004; Selam and Kelay 2013). Village chickens were housed, though the housing was not proper, a finding in agreement with results found by Mwale and Masika (2009) and Nyoni and Masika (2012). Good housing is needed to reduce losses of chickens from predators, diseases and extreme weather conditions (Kusina et al. 2001).

The current study agrees with many studies (Muchadeyi et al. 2007; Mwale and Masika 2009; Nyoni and Masika 2012), that indicated that the major reason for keeping village chickens is to provide a source of protein in the form of meat and eggs. This may be attributed to the fact that village chicken meat is highly favored by consumers because of its taste, texture, leanness, suitability for special dishes (Mtileni et al. 2009), and less fat accumulated in carcasses of indigenous chickens as compared to hybrids (Tarwireyi and Fanadzo 2013). Furthermore, chickens can be slaughtered more easily for consumption than other livestock and can be easily stored (Mwale and Masika 2009). Farmer consumed one chicken per time. The number of chickens consumed per time depends on the size of family, and in this study, the highest household size was less than five. This could explain why one chicken per time was consumed in both study sites. Moreover, consumption of one bird may be ascribed to the few numbers of chickens farmers had. Although some farmers consume eggs from the village chickens, most refrain from doing so, to provide as many eggs as possible for incubation. This result is inconsistent with Moreki et al. (2010), who reported that farmers did not consume eggs but used them for breeding. Although chickens were mainly kept for consumption, some farmers occasionally sold some of their chickens within the community, a finding consistent with the results reported by Nyoni and Masika (2012). This study is in contrast with the findings of Moges et al. (2010) and Zwedu et al. (2013), who reported sales of village chickens were the main reason for rearing chickens. 
Chicken manure was applied to vegetable gardens to enrich the fertility of soils in their gardens. This concurs with the results found by Muchadeyi et al. (2004), Nyoni and Masika (2012) and Ndiweni (2013). Chicken manure is considered to be the best for vegetables than goat and cattle manure (Mapiye et al. 2008). In addition, poultry manure is a rich source of nitrogen and organic manure which helps to improve crop production (Ndiweni 2013). Chickens were used as donation to neighbors and relatives, a finding in line with results of Nyoni and Masika (2012) and Gabanakgosi et al. (2013). Donation of chickens is expressed by many words including care, love, support, teamwork, sharing, socialization, pass-on-gift, togetherness, encouragement, appreciation and self-reliance (Gabanakgosi et al. 2013). In this study, farmers donated with their chickens to encourage their neighbors with farm village chickens. Chicken farmers in Centane didn't use chickens for cultural purposes, a finding in agreement to reports by Mwale and Masika (2009) and Nyoni and Masika (2012). However, in Mount Frere chickens were used for cultural purposes, consistent with the findings by Mafu and Masika (2003), Moreki (2006) and Mack et al. (2005). This may be attributed to the fact that village chickens are easily available as sacrificial for various cultural functions (Mwacharo et al. 2013).

The results of the current study show that village chickens play an important role in the livelihoods of farmers in South Africa, mostly on the provision of food in the form of meat and eggs. Diseases specifically Newcastle were major causes of chicken loss; hence there is a need to prevent and control this disease through vaccination. Parasites, predation, and theft were also the causes of chicken losses in Centane and Mount Frere. Improvement in management of poultry housing, feeding, and animal health care will increase village chicken productivity significantly.

\section{ACKNOWLEDGEMENTS}

The financial support from DAFF (Zero hunger) is acknowledged with gratitude. The authors are thankful for the support from the Agricultural and Rural Development Research Institute (ARDRI) and the farmers in Centane and Mount Frere, Eastern Cape Province.

\section{REFERENCES}

Abubakar MB, Ambali AG, Tamjdo T. 2007. Rural chicken production: Effects of gender on ownership, and management responsibilities in some parts of Nigeria and Cameroon. Int J Poult Sci 6: 413-416.

Adongo J. 2004. Comparative advantage of a thermotolerant I-2 vaccine in the control of Newcastle disease in village chickens in Ghana. Rural Poultry E-Newsletter, Third Edition, March 2004. http://www.iaea.org/nafa/d3/mtc/ghana.pdf.

Aklilu HA, Udo HMJ, Almekinders CJM, Van der Zijpp AJ. 2008. How resource-poor households value and access poultry: Village poultry keeping in Tigray, Ethiopia. Agric Syst 96: 175-183.

Copland JW, Alders RG. 2005. The Australian village poultry development programme in Asia and Africa. World Poult Sci J 61 : 31-37.
Dinka H, Chala R, Dawa F, Bekana E, Leta S. 2010. Major constraints and health management of village production in Rift Valley of Oromia, Ethiopia. Am Eurasian J Agric Environ Sci 9: 529-533.

Fattah KA. 1999. Poultry as a tool in poverty eradication and the promotion of gender equality. Proc. Workshop on Poultry as a Tool in Poverty Eradication and Promotion of Gender Equality. Tune Landboskole, Denmark, 22-26 March 1999. [Denmark]

Gabanakgosi K, Moreki JC, Nsoso SJ, Tsopito C. 2012. Ethnoveterinary medicine usage in family chickens in the selected four villages of Botswana. J Vet Advan 2: 586-594.

Gabanakgosi K, Moreki JC, Tsopito CM, Nsoso SJ. 2013. Impact of family chickens on the livelihoods of people living with HIV and AIDS in four villages of Botswana.Worlds Poult Sci J 3: 45-53.

Halima HM. 2007. Phenotypic and Genetic Characterization of Indigenous Chicken Populations in North-West Ethiopia. [Dissertation]. University of the Free State, Bloemfontein. [South Africa]

Kusina J, Kusina T, Mhlanga J. 2001. A survey on village chicken losses: Causes and Solutions as perceived by farmers, Proceeding of SADC Planning Workshop in Newcastle disease control in village chickens. Proceedings 103. ACIAR, Canberra [Australia]

Kusina JF, Kusina NT, Mhlanga J. 2004. A survey on village chicken losses: causes and solutions as perceived by farmers. Pp148-155. https://pdfs.semanticscholar.org/98ea/61e95455aee91861069a82193a e79ef58090.pdf.

Mack S, Hoffman D, Otte J. 2005. The contribution of poultry to rural development. World Poult Sci J 69: 7-13.

Mafu JV, Masika PJ. 2003. Smallscale broiler production by rural farmers in the central Eastern Cape Province of South Africa. Fort Hare Pap 12: $25-34$.

Mapiye C, Mwale M, Mupangwa JF, Chimonyo M, Foti R, Mutenje MJ. 2008. A research review of village chick production constraints and opportunities in Zimbabwe. Asian-Australas J Anim Sci 21: 16801688

Moges F, Mellesse A, Dessie T. 2010. Assessment of village production system evaluation of the productive and reproductive performance of local chicken ecotype in Bure district, North West Ethiopia. Afr J Agric Res 5: 1739-1748

Moreki JC. 2006. Family poultry production. Poultry Today. Ministry of Agriculture, Gaborone, Botswana

Moreki JC. 2010. Opportunities and challenges for the Botswana poultry industry in the 21 st century: a review. Livestock Res Rural Dev 22 (5). http://www.lrrd.org/lrrd22/5/moreb22089.htm.

Mtileni BJ, Muchadeyi FC, Maiwashe A, Phitsane PM, Halimani TE. 2009. Characterisation of production systems for indigenous chicken genetic resources of South Africa. Appl Anim Husb Rural Dev 2: 18 22.

Muchadeyi FC, Sibanda S, Kusina NT, Kusina J, Makuza S. 2004. The village chicken production system in Rushinga District of Zimbabwe. Livest Res Rural Dev16: (6)

Muchadeyi FC, Wollny CBA, Eding H, Weigend S, Makuza SM, Simianer H. 2007. Variation in village production systems among agro-ecological zones of Zimbabwe. Institute of Animal Breeding Mariensee. Federal Research centre. Germany. Trop Anim Health Pro 39: 453-461.

Mutibvu T, Maburutse BE, Mbiriri DT, Kashangura MT. 2012. Constraints and opportunities for increased livestock production in communal areas: A case study of Simbe, Zimbabwe. Livest Res Rural Dev 24: (9)

Mwacharo JM, Bjørnstad G, Han JL, Hanotte O. 2013. The history of African village chickens: an archaeological and molecular perspective. Afr Archaeol Rev 30: 97-114.

Mwale M, Masika PJ. 2009. Ethno-veterinary control of parasites, management and role of village chickens in rural households of Centane district in the Eastern Cape, South Africa. Trop Anim Health Pro 41: 685-699.

Ndiweni NJ. 2013. Prudent poultry farming as a source of livelihood and food security in changing the climate: The case of Zhombe communal lands, Zimbabwe. Int J Sci Res Publ 22503153.

Nnadi PA, George SO. 2010. A cross-sectional survey on parasites of chickens in selected villages in the Subhumid Zones of South-Eastern Nigeria. J Parasitol Res 2010: 1-6.

Nyoni NMB, Masika PJ. 2012. Village chicken production practices in the Amathole Basin of the Eastern Cape Province, South Africa. Afr J Agric Res 7: 2647-2652. 
Phininzi K, Ngetar S. 2017. Mapping soil erosion in a quaternary catchment in Eastern Cape using geographic information system and remote sensing. S Afr J Geomat 6: 1-19.

Reta D. 2009. Understanding the role of indigenous chickens during the long walk to food security in Ethiopia. Livest Res Rural Dev 21: (8).

Selam M, Kelay B. 2013. Causes of village chicken mortality and interventions by, farmers in Ada's District, Ethiopia. Int J Livest Prod 4: 88-94.
Tarwireyi L, Fanadzo M. 2013. Production of indigenous chickens for households food security in rural KwaZulu-Natal, South Africa. Afr J 8: 5832-5840.

Zwedu S, Kassa B, Agza B, Alemu F. 2013. Village chicken production system in Metekel zone, Northwest Ethiopia. Wudpecker J Agric Res 2: $256-262$. 